๑О. М. Павловська, К. М. Павловська, Ж. О. Краснова

Одесъкий національний медичний університет

\title{
ПОРІВНЯЛЬНА ОЦІНКА ЕФЕКТИВНОСТІ РІЗНИХ СХЕМ МЕДИКАМЕНТОЗНОЇ КОРЕКЦІї ЗОВНІШНЬОГО ГЕМОРОЮ У ПОРОДІЛЬ
}

Мета дослідження - дослідити есрективність різних схем медикаментозного лікування при виникненні зовнішнього геморою у породіль.

Матеріали та методи. Було обстежено 48 жінок віком 28-45 років з діагностованим зовнішнім гемороєм у післяпологому періоді. Породіль було розділено на дві групи залежно від призначеного медикаментозного лікування. Пацієнтки I групи отримували комплексну медикаментозну терапію, до складу якої було включено пребіотик («Дусралак»), ангіопротектор/венотонік («Нормовен») та ректальні антигемороїдальні супозиторії («Натальсид»). Породіллі ІІ групи отримували монотерапію у вигляді ректальних антигемороїдальних супозиторіїв («Натальсид»). Також під час лікування обов'язково рекомендували дотримання певних правил харчування. Усім пацієнткам проводили рутинне клініко-лабораторне обстеження. Контроль есрективності лікування здійснювали через 7 та 14 днів. Також проводили динамічне спостереження протягом 12 місяців для аналізу тривалості лікувального ефекту та фріксації рецидивів зовнішнього геморою в обстежених пацієнток.

Результати дослідження та їх обговорення. Покращення загального стану, самопочуття та нівелювання основних клінічних ознак зовнішнього геморою після 7-денного лікування відмітила переважна більшість жінок I групи - 83,3 \% та 62,5 \% породіль II групи, які отримували монотерапію. Після двотижневого курсу терапії цей показник становив 95,8 \% та 75,0 \% відповідно. При проведенні проспективного аналізу встановлено, що при застосуванні лише препаратів локальної дії рецидиви захворювання протягом року фріксувалися в 16,7 \% випадків. У групі жінок, яким була рекомендована медикаментозна корекція, яка впливала на різні патогенетичні ланки фрормування даного захворювання прямої кишки, цей показник склав лише 4,2\%.

Висновки. При загостренні або виникненні зовнішнього геморою в жінок у післяпологовому періоді прогностично виправданим та раціональним є призначення саме комплексної медикаментозної терапії. Важливо не тільки нівелювати локальні прояви даної патології прямої кишки, але впливати на різні патогенетичні складові її фрормування. Так, фрізіологічна санація та стимуляція перистальтичної активності кишечника за допомогою пребіотиків, призначення ангіопротекторів/венотоніків системної дії загалом сприяють досягненню довготривалої ремісії захворювання. Застосування при зовнішньому геморої лише препаратів з локальною дією має позитивний, проте іноді короткотривалий лікувальний ефект.

Ключові слова: післяпологовий період; ускладнення післяпологового періоду; зовнішній геморой; медикаментозна корекція геморою.

СРАВНИТЕЛЬНАЯ ОЦЕНКА ЭФФЕКТИВНОСТИ РАЗНЫХ СХЕМ МЕДИКАМЕНТОЗНОЙ КОРРЕКЦИИ НАРУЖНОГО ГЕМОРРОЯ У РОДИЛЬНИЦ

Цель исследования - изучить эффрективность разных схем медикаментозного лечения при фрормировании наружного геморроя у родильниц.

Материалы и методы. Было обследовано 48 женщин в возрасте 28-45 лет с диагностированным наружным геморроем в послеродовом периоде. Родильницы были разделены на две группы в зависимости от схемы медикаментозной коррекции. Пациентки I группы получали комплексную терапию, в состав которой были включены пребиотик («Дусралак»), ангиопротектор/венотоник («Нормовен») и ректальные антигеморроидальные суппозитории («Натальсид»). Пациентки II группы получали монотерапию в виде ректальных антигеморроидальных свечей («Натальсид»). Также во время лечения настоятельно рекомендовалось соблюдение определенной диеты. Всем родильницам было проведено рутинное клиниколабораторное обследование. Контроль эффрективности лечения проводили через 7, 14 дней. Также осуществляли динамическое наблюдение в течение 12 месяцев для анализа продолжительности лечебного эфффекта и сриксации возможных рецидивов наружного геморроя в обследованных пациенток.

Результаты исследования и их обсуждение. Улучшение общего состояния, самочувствия и нивелирование основных клинических проявлений наружного геморроя после 7-дневного лечения отметило подавляющее большинство женщин I группы - 83,3 \% и 62,5 \% родильниц II группы, которые получали монотерапию. После двухнедельного курса терапии этот показатель был 95,8 \% и 75,0 \% соответственно. При проведении проспективного анализа установлено, что при назначении только препаратов локального действия рецидивы заболевания в течение года фриксировались в 16,7 \% случаев. В группе пациенток, которым была рекомендована схема лечения, коррегирующая основные патогенетические механизмы сормирования данной патологии прямой кишки, этот показатель составил лишь 4,2%.

Выводы. При обострении или возникновении наружного геморроя у женщин в послеродовом периоде прогностически наиболее оправданным и рациональным является назначение именно комплексной медикаментозной терапии. Важно не только устранить локальные проявления данной патологии прямой кишки, но и скорректировать различные патогенетические механизмы ее формирования. Так, физиологическая санация и стимуляция перистальтической активности кишечника с помощью пребиотиков, назначение ангиопротекторов/венотоников системного действия в целом способствуют достижению долговременной ремиссии заболевания. Применение же при наружном геморрое только препаратов локального действия имеет положительный, однако подчас кратковременный лечебный эффект.

Ключевые слова: послеродовой период; осложнения послеродового периода; наружный геморрой; медикаментозная коррекция геморроя. 


\section{COMPARATIVE EVALUATION OF THE EFFICACY OF DIFFERENT SCHEMES OF DRUG CORRECTION OF EXTERNAL HEMORRHOIDS IN PUERPERAS}

The aim of the study - to learn the efficacy of different schemes of drug treatment in the formation of external hemorrhoids in puerperas.

Materials and Methods. We examined 48 women aged 28-45 years with diagnosed external hemorrhoids in the postpartum period. The puerperas were divided into two groups depending on the scheme of drug correction. The patients of the group I received complex therapy, which included a prebiotic (Dufalac), an angioprotector/venotonic (Normoven), and rectal antihemorrhoidal suppositories (Natalsid). The patients in the group II received monotherapy in the form of rectal antihemorrhoidal suppositories (Natalcid). It was also strongly recommended to follow a certain diet during treatment. All puerperas underwent routine clinical and laboratory examination. Monitoring the effectiveness of treatment was performed in 7, 14 days. Dynamic follow-up was also carried out for 12 months to analyze the duration of the therapeutic effect and fix possible recurrences of external hemorrhoids in the examined patients.

Results and Discussion. Improvement of the general condition, well-being and elimination of the main clinical manifestations of external hemorrhoids after 7 days of treatment was noted by the overwhelming majority of women in the group I $-83.3 \%$ and $62.5 \%$ of puerperas in the group II who received monotherapy. After a two-week course of therapy, this index was $95.8 \%$ and $75.0 \%$, respectively. When conducting a prospective analysis, it was established that when prescribing only drugs of local action, recurrences of the disease were recorded in $16.7 \%$ of cases during a year. In the group of patients who were recommended a treatment regimen that corrects the main pathogenetic mechanisms of the formation of this pathology of the rectum, this figure was only $4.2 \%$.

Conclusions. In exacerbation or the occurrence of external hemorrhoids in women in the postpartum period, the administration of the complex drug therapy is the most reasonable and rational. It is important not only to eliminate the local manifestations of this pathology of the rectum, but also to correct the various pathogenetic mechanisms of its formation. Thus, physiological sanitation and stimulation of the intestinal peristaltic activity with the help of prebiotics, the appointment of systemic angioprotectors/venotonics, generally contribute to the achievement of long-term remission of the disease. The use of only local preparations with external hemorrhoids has a positive, however, sometimes short-term therapeutic effect.

Key words: postpartum period; postpartum complications; external hemorrhoids; drug correction of hemorrhoids.

ВСтУП. За даними сучасних клінічних досліджень, геморой у жінок $€$ найбільш поширеним колопроктологічним захворюванням [1]. Це обумовлено не тільки значною кількістю тригерних факторів, але й певними своєрідними анатомічними особливостями прямої кишки. Відомо, що під слизовою оболонкою прямої кишки розташоване венозне (гемороїдальне, кавернозне) сплетення, яке фріксоване до стінок анального каналу зв'язкою Паркса i/або м'язом Трейца. При тривалому порушенні відтоку крові судини гемороїдального сплетення поступово втрачають еластичність, розширюються та випинаються під слизову оболонку. Згодом відбувається опущення самої ректальної слизової оболонки, що супроводжується посиленням венозного стазу, ініціацією гіперпластичних процесів у дистальному відділі кишки та анусі [2].

Основними пусковими моментами фрормування геморою в жінок є хронічні закрепи та малорухливий спосіб життя [3, 4]. Проте саме вагітність й пологи найчастіше сприяють формуванню даної колопроктологічної проблеми ще в молодому віці [5]. Так, із перших тижнів вагітності фрізіологічна гіперпрогестеронемія обумовлює зниження тонусу гладком'язових клітин середньої оболонки венозних судин. Згодом, зі збільшенням терміну гестації, вагітна матка стискає нижню порожнисту вену, тазові вени, венозні сплетення, а також безпосередньо стінки прямої кишки. Під час пологів, особливо довготривалих, у роділлі значно підвищується внутрішньочеревний тиск, тому ризик виникнення геморою або його загострення в післяпологовому періоді значно зростає. За результатами багатоцетрових досліджень, геморой діагностується у 28-37 \% вагітних й 41-50 \% породіль $[6,7]$.

Під час вагітності фрормування або загострення геморою супроводжується неприємними відчуттями, значним дискоморортом, порушенням спорожнення кишечника, що у більшості випадків потребує призна- чення відповідної медикаментозної терапії. Слід зазначити, що на сучасному етапі розвитку фрармакології переважна більшість цих препаратів не відноситься до бажаної категорії «А» за впливом на вагітність, коли «не існує ризику в контрольованих дослідженнях людини». На жаль, ліки, що пропонуються при цій патології, у більшості випадків відносяться до категорії «В», іноді навіть «С», отже, становлять певну небезпеку для плода. 3 другого боку, вельми небезпечними можуть бути й ускладнення геморою. Зокрема, безпосередніми наслідками захворювання є тріщини та нориці прямої кишки, тромбоз гемороїдальних вузлів, парапроктит, анальний поліпоз, які обумовлюють широкий спектр щоденних неприємних відчуттів, іноді виразний, нестерпний біль при дефекації, сприяють виникненню та поширенню запальних процесів в органах малого таза, а також при тривалому перебігу й ігноруванні проблеми нерідко ініціюють процеси малігнізації $[8,9]$.

Отже, геморой - це дуже делікатна й досить специфрічна хвороба, яка може значно погіршувати загальне самопочуття жінки, знижувати якість її повсякденного життя та мати іноді невиправні наслідки, тому потребує своєчасної діагностики, ефрективного лікування та ретельного самоконтролю з боку жінки.

МЕТА ДОСЛІДЖЕННЯ - дослідити ефективність різних схем медикаментозного лікування при виникненні зовнішнього геморою у породіль.

МАТЕРІАЛИ ТА МЕТОДИ. БУЛо обстежено 48 породіль віком 28-45 років з клінічними ознаками зовнішнього геморою.

Діагноз виставляли на підставі скарг породіллі на дискомфорт у ділянці анального отвору, свербіж, відчуття наявності стороннього тіла у прямій кишці та/або неповного випорожнення, наявність слизу та/або кров'яних виділень у калових масах. При огляді - подразнення навколо 
ануса, припухлість й гіперемія, наявність характерних, набрякових гемороїдальних вузлів ціанотичного кольору.

Пацієнток було розділено на дві групи:

I група - 24 пацієнтки, які страждали від проявів зовнішнього геморою та отримували комплексну медикаментозну терапію, до складу якої увійшли «Нормовен», «Дусралак» та «Натальсид».

II група - 24 жінки, яким у післяпологовому періоді у зв'язку із діагностуванням зовнішнього геморою призначали монотерапію у вигляді ректальних антигемороїдальних супозиторіїв «Натальсид».

«Нормовен» (виробник ЗАТ «Київський вітамінний завод», м. Київ, Україна) - ангіопротективний, капіляростабілізуючий, протинабряковий, протизапальний засіб, основними діючими інгредієнтами є діосмин (450 мг) та гесперидин (50 мг). Препарат стабілізує лізосомальні мембрани, гальмує вивільнення аутолітичних клітинних ферментів, що розщеплюють протеоглікани, зменшує патологічно підвищену судинно-тканинну проникність і ламкість капілярів, попереджує транскапілярну фрільтрацію низькомолекулярних білків, електролітів і води у міжклітинний простір, попереджує венозний застій та тромбоз, підвищує тонус венозної стінки. Препарат призначали по 2 таблетки тричі на день протягом перших 4 діб, 2 таблетки двічі на день протягом наступних 3 діб, потім по 1 таблетці двічі на день протягом 2 місяців.

«Дусралак» (виробник компанія «Solvay Pharmaceuticals», Нідерланди) - пребіотик, основним діючим інгредієнтом якого $є$ лактулоза. Відомо, що метаболіти лактулози є ідеальними живильними речовинами для біфрідо- й лактобактерій, знижують рН вмісту товстої кишки до слабко кислих значень, підвищують осмотичний тиск у її просвіті. Загалом це сприяє, по-перше, елімінації потенційно патогенної мікрофрлори, токсинів, отже, санації кишечника. По-друге, обумовлює розм'якшення та збільшення об'єму хімусу, стимуляцію перистальтичної активності, що клінічно супроводжується м'якою проносною дією, без виникнення спазмів та водно-електролітних порушень, що має винятково важливе значення у післяпологовому періоді зокрема. «Дусралак» призначали по 15-20 мл 3 рази на добу протягом 14 днів.

Активною діючою речовиною ректальних супозиторіїв «Натальсид» є натрію альгінат - природний полісахарид, який отримують з бурих морських водоростей. Препарат має виразні протизапальні, регенеруючі, кровоспинні й тонізуючі властивості, ефективний для лікування геморою різної етіології. Призначали по 1 супозиторію двічі на добу. Курс лікування складав 14 днів.

Побічних ефректів медикаментозної терапії під час лікування у пацієнток обох груп не спостерігали.

Ключовим компонентом лікувальних заходів було також дотримування породіллями й певної дієти. Пацієнткам рекомендували вживати достатню кількість рідини (не менше 1,5-2 літрів на добу): морси, соки з темних ягід, узвар, легкий чай і кисломолочні суміші, збагачені корисною мікрофрлорою (лакто- і біфрідобактеріальні культури). Хліб - лише виготовлений із борошна грубих сортів і висівковий, злегка підсохлий. Серед круп'яних виробів віддавали перевагу перловці, гречці, ячневій крупі. Вживання пісних м'ясних (курятина, кролятина, індичатина) і рибних (судак, лобань, камбала) страв було допустимо, проте без застосування спецій. Овочі можна було вживати будь-які, але перевагу віддавали буряку, кабачкам, гарбузу, моркві, броколі, цвітній, брюссельській капусті, огіркам і помідорам, як у свіжому, так і в дієтично приготованому вигляді (на парі, тушкованим, запеченим). Окремо рекомендували морську капусту у вигляді салатів і гарнірів до страв. 3 фрруктів - ківі, хурма, яблука, банани, абрикоси, сливи, а також різні сухофррукти.

Усім пацієнткам у післяпологовому періоді проводили рутинне клініко-лабораторне обстеження та медикаментозне лікування згідно з наказами МОЗ України.

Для обробки результатів дослідження використовували метод варіаційної статистики і непараметричні методи за допомогою програм «Excel-2000» i «Statistica for Windows v.6.0».

РЕЗУЛЬТАТИ ДОСЛІДЖЕННЯ ТА ЇХ ОБГОВОРЕННЯ. Важливою метою нашого дослідження було проведення ретельного аналізу можливих тригерних моментів виникнення зовнішнього геморою у післяпологовому періоді. Цікавим виявився той фракт, що у $13(27,1$ \%) жінок ознаки хвороби вперше маніфестували вже після перших (даних) пологів. У 28 (58,3 \%) породіль наявні пологи були другими або третіми, у 7 (14,6 \%) - четвертими та більше. Це свідчить про те, що навіть перша вагітність і пологи $€$ вагомим фрактором ризику формування даної патології прямої кишки, отже, потребує уваги з боку пацієнтки та лікаря й проведення належних профрілактичних заходів.

Слід зазначити, що значущими чинниками фрормування геморою в обстежених породіль виявилися щоденна тривала сидяча/стояча робота (45,8 \%) та малорухливий сучасний спосіб життя (37,5\%). Переважна більшість жінок саме їх визнала першорядними, також пов'язуючи з ними й наявність частих закрепів до та під час вагітності (табл. 1).

Також необхідно підкреслити, що варикозна хвороба була діагностована у значної кількості пацієнток - 26 (54,2 \%), отже, у кожної другої. Під час анкетування нами була виявлена й прихильність багатьох жінок до вживання гострих, жарених, жирних страв (43,8 \%). На шкідливі звички (куріння, вживання алкогольних напоїв до та під час вагітності) вказали 11 (22,9 \%) породіль.

Наступним кроком нашого клінічного дослідження було визначення ефективності запропонованих схем лікування та проведення порівняльного аналізу. Покращення загального стану, самопочуття та нівелювання проявів зовнішнього геморою після 7 днів лікування відмітила переважна більшість породіль I групи, яким призначили комплексну медикаментозну терапію, - 20 (83,3 \%). У пацієнток, що отримували монотерапію у вигляді ректальних антигемороїдальних супозиторіїв за той самий проміжок часу, ефективним лікування визначили 15 (62,5 \%) жінок (табл. 2). Приблизно 30 \% пацієнток II групи після тижневого курсу лікування скаржилися на певний дискомфорт і свербіж у ділянці анального отвору, неприємні відчуття під час спорожнення кишечника, схильність до закрепів.

Проведене анкетування та огляд через 14 днів після розпочатої медикаментозної корекції довели доцільність призначення саме комбінованої терапії зовнішнього геморою, яка передбачає застосування ангіопротекторів/ венотоніків, пребіотиків та локально діючих протизапальних, регенеруючих й кровоспинних засобів. Отже, серед пацієнток I групи через 2 тижні лише одна жінка вказала на наявність періодичного дискомсорту в ділянці аноректальної зони. Обстежені жінки II групи також відмітили 
позитивну динаміку лікування, проте приблизно $20 \%$ пацієнток не оцінили свій стан як абсолютно здоровий.

Кінцевим завданням нашого проспективного дослідження було фріксація випадків рецидиву зовнішнього геморою через два проміжки часу - через 6 та 12 місяців (табл. 3).
Визначено, що призначення комплексної медикаментозної терапії зовнішнього геморою, що виник після пологів, є доцільним, ефективним та довготривалим. При застосуванні лише антигемороїдальних препаратів 3 локальним ефектом дії можливі рецидиви захворювання протягом року в 16,7 \% випадків.

Таблиця 1. Анамнестичні дані пацієнток із загостренням геморою у післяпологовому періоді (n=48)

\begin{tabular}{|l|c|}
\hline Малорухливий спосіб життя & $37,5 \%(18)$ \\
\hline Надмірні фрізичні навантаження & $2,1 \%(1)$ \\
\hline Щоденна сидяча або стояча робота & $45,8 \%(22)$ \\
\hline Паритет (2 та більше пологів в анамнезі) & $72,9 \%(35)$ \\
\hline Обтяжений сімейний анамнез & $12,5 \%(6)$ \\
\hline Варикозна хвороба & $54,2 \%(26)$ \\
\hline Ожиріння & $14,6 \%(7)$ \\
\hline Хронічні закрепи & $64,6 \%(31)$ \\
\hline Синдром подразненого кишечника & $4,2 \%(2)$ \\
\hline Запальні або пухлинні процеси органів малого таза & $10,4 \%(5)$ \\
\hline Куріння до та під час вагітності & $22,9 \%(11)$ \\
\hline Вживання алкоголю до та під час вагітності & $6,25 \%(3)$ \\
\hline Вживання гострої, жареної, жирної їжі & $43,8 \%(21)$ \\
\hline
\end{tabular}

Таблиця 2. Динаміка клінічної ефективності медикаментозної терапії

\begin{tabular}{|c|c|c|c|c|}
\hline \multirow{2}{*}{ Клінічні ознаки хвороби } & \multicolumn{2}{|c|}{ I група (n=24) } & \multicolumn{2}{|c|}{ II група (n=24) } \\
\hline & 7 діб лікування & 14 діб лікування & 7 діб лікування & 14 діб лікування \\
\hline Дискомфорт у ділянці анального отвору & $4(16,7 \%)$ & $1(4,2 \%)$ & $8(33,3 \%)$ & $5(20,8 \%)$ \\
\hline Свербіж & $4(16,7 \%)$ & 0 & $4(16,7 \%)$ & $2(8,3 \%)$ \\
\hline Відчуття неповного випорожнення кишечника & 0 & 0 & $9(37,5 \%)$ & $6(25 \%)$ \\
\hline $\begin{array}{l}\text { Наявність слизу та/або кров'яних виділень у } \\
\text { калових масах }\end{array}$ & $3(12,5 \%)$ & 0 & $3(12,5 \%)$ & 0 \\
\hline
\end{tabular}

Таблиця 3. Оцінка ефективності лікування через 6 та 12 місяців

\begin{tabular}{|l|c|c|c|c|}
\hline \multirow{2}{*}{ Показник } & \multicolumn{2}{|c|}{ I група $(\mathrm{n}=24)$} & \multicolumn{2}{c|}{ II група $(\mathrm{n}=24)$} \\
\cline { 2 - 5 } & 6 місяців & 12 місяців & 6 місяців & 12 місяців \\
\hline Відсутність рецидиву & $24(100 \%)$ & $23(95,8 \%)$ & $21(87,5 \%)$ & $20(83,3 \%)$ \\
\hline Загострення геморою & 0 & $1(4,2 \%)$ & $3(12,5 \%)$ & $4(16,7 \%)$ \\
\hline
\end{tabular}

ВИСноВКИ. 1. При загостренні або виникненні зовнішнього геморою в жінок у післяпологовому періоді прогностично виправданим та раціональним $€$ призначення саме комплексної медикаментозної терапії. Важливо не тільки нівелювати локальні прояви даної патології прямої кишки, але й впливати на різні патогенетичні складові їі фрормування. Так, фрізіологічна санація та стимуляція перистальтичної активності кишечника за допомогою таких безпечних і дієвих засобів, як пребіотики, призначення ангіопротекторів/венотоніків системної дії загалом сприяють досягненню довготривалої ремісії захворювання.

2. Застосування при зовнішньому геморої препаратів 3 локальною дією має позитивний лікувальний ефект у достатньої кількості клінічних випадків, проте лише в короткотривалій перспективі. Отже, у порівняльному та прогностичному плані така схема $€$, безумовно, менш раціональною.

ПЕРСПЕКТИВИ ПОДАЛЬШИХ ДОСЛІДЖЕНЬ. ДОслідити особливості призначення комплексної медикаментозної терапії у вагітних жінок, що страждають від загострення геморою. Детально вивчити ефективність дієтотерапії для даної категорії пацієнток. Визначити дієвість просрілактичних засобів під час вагітності. У межах отриманих результатів доповнити існуючі клінічні протоколи рекомендаціями щодо профрілактики й своєчасної медикаментозної корекції даної патології. 


\section{СПИСОК ЛІТЕРАТУРИ}

1. Lohsiriwat V. Treatment of hemorrhoids: A coloproctologist's view / V. Lohsiriwat // World J. Gastroenterol. - 2015. Vol. 21 (31). - P. 9245-9252.

2. Jacobs D. Clinical practice. Hemorrhoids / D. Jacobs // N. Engl. J. Med. - 2014. - Vol. 371 (10). - P. 944-9451.

3. Haemorrhoids and anal fissures during pregnancy and after childbirth: a prospective cohort study / T. Poskus, D. Buzinskienè, G. Drasutiene [et al.] // BJOG. - 2014. Vol. 121(13). - P. 1666-1671.

4. Avsar A. F. Haemorrhoids during pregnancy / A. F. Avsar, H. L. Keskin // J. Obstet. Gynaecol. - 2010. - Vol. 30(3). P. 231-237.

\section{REFERENCES}

1. Lohsiriwat, V. (2015). Treatment of hemorrhoids: A coloproctologist's view. World J. Gastroenterol., 21 (31), 9245-9252.

2. Jacobs, D. (2014). Clinical practice. Hemorrhoids. N. Engl. J. Med., 371 (10), 944-951.

3. Poskus, T., Buzinskiene, D., Drasutiene, G., Samalavicius, N.E., Barkus, A., Barisauskiene, A., ... \& Jakaitiene, A. (2014). Haemorrhoids and anal fissures during pregnancy and after childbirth: a prospective cohort study. BJOG., 121 (13) 1666-1671.

4. Avsar, A.F., \& Keskin, H.L. (2010). Haemorrhoids during pregnancy. J. Obstet. Gynaecol., 30 (3), 231-237.

5. Ahlund, S., Radestad, I., Zwedberg, S., Edqvist, M., \& Lindgren, H. (2018). Haemorrhoids - A neglected problem faced by women after birth. Sex Reprod. Healthc. 18, 30-36.
5. Haemorrhoids - a neglected problem faced by women after birth / S. Ahlund, I. Radestad, S. Zwedberg [et al.] // Sex Reprod. Healthc. - 2018. - Vol. 18. - P. 30-36.

6. Abramowitz L. Management of hemorrhoid disease in the pregnant woman / L. Abramowitz // Castroenterol. Clin. Biol. 2008. - Vol. 32. - P. 210-214.

7. Hemorrhoids in pregnancy / A. Staroselsky, A. A. NavaOcampo, S. Vohra, G. Koren // Can Fam Physician. - 2008. - Vol. 54 (2). - P. 189-190.

8. The significance of detailed examination of hemorrhoids during pregnancy / M. Gojnic, V. Dugalic, M. Papic [et al.] // Clin. Exp. Obstet. Gynecol. - 2005. - Vol. 32 (3). P. 183-184.

9. Lohsiriwat V. Hemorrhoids: from basic pathophysiology to clinical management / V. Lohsiriwat // World J. Gastroenterol. - 2012. - Vol. 18 (17). - P. 2009-2017.

6. Abramowitz, L. (2008). Management of hemorrhoid disease in the pregnant woman. Castroenterol. Clin. Biol., 32, 210-214.

7. Staroselsky, A., Nava-Ocampo, A.A., Vohra, S., \& Koren, G. (2008). Hemorrhoids in pregnancy. Can Fam. Physician., 54 (2), 189-190.

8. Gojnic, M., Dugalic, V., Papic, M., Vidakovic, S., Milicevic, S., \& Pervulov, M. (2005). The significance of detailed examination of hemorrhoids during pregnancy. Clin. Exp. Obstet. Gynecol., 32 (3), 183-184.

9. Lohsiriwat, V. (2012). Hemorrhoids: from basic pathophysiology to clinical management. World J. Gastroenterol., 18 (17), 2009-2017. 